\title{
Private Self-consciousness, Self-reflection, Insight and Alcohol Consumption Among Young People and Adults
}

\author{
Cristyan Karla Nogueira Leal \\ Gabriel Gonzaga Barbosa de Faria ${ }^{1}$ \\ Mariane Lima DeSoura ${ }^{1}$ \\ ${ }^{1}$ Universidade Federal do Espirito Santo, Vitória, ES
}

\begin{abstract}
Private self-consciousness is a relevant metacognitive capacity in the self-regulation process, with possible implications in alcohol consumption. This research verified the influence of self-reflection and insight, dimensions of private self-consciousness, on drinking behavior. A total of 523 Brazilians, aged from 20 to 39 years old, participated in a survey by answering the SelfReflection and Insight Scale and the AUDIT test. The results showed that women have higher levels of self-reflection, whereas men have higher levels of insight. With regard to alcohol consumption, young people drink at higher risk levels than adults. Selfreflection and insight were negatively correlated with alcohol consumption. Age and gender differences in the intensity of the correlation between variables and the influence of environmental factors on the regulation of drinking behavior are discussed. Keywords: self-reflection; insight; self-regulation; youth; alcohol consumption
\end{abstract}

\section{Autoconsciência Privada, Autorreflexão, Insight e Consumo de Álcool Entre Jovens e Adultos}

\begin{abstract}
Resumo
A autoconsciência privada é uma capacidade metacognitiva relevante no processo de autorregulação, com possível implicação no consumo de álcool. Esta pesquisa objetivou verificar a relação da autorreflexão e do insight, dimensões da autoconsciência privada, no comportamento de beber. Participaram 523 brasileiros, de 20 a 39 anos que responderam à Escala de Autorreflexão e Insight e ao teste AUDIT. Os resultados indicaram que mulheres apresentam níveis mais elevados de autorreflexão, enquanto homens, de insight. Quanto ao consumo de álcool, jovens bebem em níveis considerados mais arriscados do que adultos. A autorreflexão e o insight correlacionaram negativamente com o consumo de álcool. Diferenças etárias e de gênero na intensidade da correlação entre variáveis e a influência de fatores ambientais na regulação do beber são discutidas.

Palavras-chave: autorreflexão, insight, autorregulação, juventude, consumo de álcool
\end{abstract}

Autoconciencia Privada, Autorreflexión, Insight y Consumo de Alcohol Entre Jóvenes y Adultos

\section{Resumen}

La autoconciencia privada es una capacidad metacognitiva relevante en el proceso de autorregulación, con posibles implicaciones en el consumo de alcohol. Esta investigación verificó la relación entre autorreflexión e Insight, dimensiones de la autoconciencia privada, en el comportamiento de beber. Participaron 523 brasileños (20 a 39 años) que respondieron la Escala de Autorreflexión e Insight y el test AUDIT. Los resultados estadísticos mostraron que las mujeres tienen mayores niveles de autorreflexión, mientras que los hombres de Insight. En cuanto a consumo de alcohol, los jóvenes beben en niveles considerados más arriesgados que los adultos. Autorreflexión e Insight se correlacionaron negativamente con el consumo de alcohol. Se discuten las diferencias de edad y género con relación a la intensidad de correlación entre las variables y la influencia de factores ambientales en la regulación de beber.

Palabras clave: autorreflexión; Insight; autorregulación; juventud; consumo de alcohol

\section{Introduction}

Alcohol is the most widely used licit drug in Brazil. Its abuse, especially among young people, has potentiated the occurrence of damages and losses to individuals and society and is becoming a public health problem (Brazilian Institute of Geography and Statistics [IBGE], 2013; Melcop, Chagas, \& Agripino, 2011; World Health Organization [WHO], 2014). According to data from IBGE (2013), 24\% of Brazilians aged 18 or over have a habit of consuming alcoholic beverages one or more times per week. Alcohol consumption is higher among men $(36.3 \%)$, young people and adults aged from 25 to 39 years old $(28.5 \%)$, closely followed by those aged from 18 to 24 years old $(27.1 \%)$, and among people with higher education $(30.5 \%)$.

When compared to 20 other countries, Brazil occupies the second position in the ranking of users who feel they have drunk more than they would have liked in the last month (27.5\%), behind Ireland (29\%), and it is six positions over the average (20.7\%) (Madruga, 2016). Among men, $57.1 \%$ drink at levels considered 
risky by the World Health Organization (WHO) and, among women, this percentage is $44.3 \%$. The same survey showed that $30.2 \%$ of "drinkers" in the country would like to drink less and, of those, $10.4 \%$ showed an interest in getting help to drink less.

Important cognitive processes such as abstraction, cognitive flexibility, decision making, inhibitory control, motor programming, attention, and self-regulation are impaired by alcohol consumption (Domingues, Mendonça, Laranjeira, \& Nakamura-Palacios, 2009; Squeglia \& Gray, 2016; WHO, 2016). These losses are even more evident in the population between 20 and 30 years old, since their frontal lobes, required in planning, control, and behavioral regulation, are still in the process of maturation (Domingues et al., 2009; Squeglia \& Gray, 2016; WHO, 2016).

Environmental and individual factors may influence individuals both protecting or making them more vulnerable to harmful alcohol consumption and its direct and indirect consequences (Reisdorfer, Büchele, Pires, \& Boing, 2012; West, 2013). Among individual factors, private self-consciousness as a human tendency or willingness to focus attention on one's own thoughts, feelings and behaviors may constitute a relevant metacognitive capacity in the process of behavioral regulation (Grant, Franklin, \& Langford, 2002). In the Brazilian context, although alcohol consumption is an important and widely investigated sociocultural phenomenon, publications that explore its relationship with private self-consciousness are yet to be found.

Empirical studies (Bartholow, Sher, \& Strathman, 2000; Foster, Neighbors, \& Young, 2014; LaBrie, Hummer, \& Neighbors, 2008; LaBrie, Pedersen, Neighbors, \& Hummer, 2008; Park, Sher, \& Krull, 2006) that sought to verify the influence of dispositional self-consciousness on alcohol consumption and its consequences mostly used the Fenigstein, Scheier, and Buss (1975) Self-Consciousness Scale (SCS). In addition to the dimensions of self-consciousness proposed by these authors (private, public, and social anxiety), these studies include other variables that could modify this influence, such as depression (Timary et al., 2013); drink refusal self-efficacy and implicit drinking identity (Foster et al., 2014); perceived social norms (LaBrie, Hummer, et al., 2008); belonging to a group (Park et al., 2006); expectations of alcohol intake (Bartholow et al., 2000) and gender (Foster et al., 2014; LaBrie, Pedersen, et al., 2008; Park et al., 2006). In a prevalent way, the conclusions of these surveys evidenced the influence of dispositional self-consciousness on the consumption of alcohol. However, the disposition of this relationship is not regular, as private self-consciousness acts in the consumption of alcohol sometimes as a protection factor, and sometimes as a risk factor.

The beneficial action of private self-consciousness in the regulation of drinking behavior was verified among university students, in a study that indicated a negative correlation between private self-consciousness levels and alcohol consumption (Labrie, Pedersen, et al., 2008). This result corroborates another that pointed to private self-consciousness as moderator of the relationship between expectations of alcohol intake and the actual quantity and frequency of use, guiding decision-making and involvement with the substance (Bartholow et al. 2000).

Nonetheless, by including the variables gender, attitudes and beliefs, the relationship between self-consciousness and alcohol consumption becomes more complex, and the association between a higher level of self-consciousness and lower alcohol consumption is not always verified. Park, Sher, and Krull (2006), when assessing the moderating potential of dispositional self-consciousness in the relationship between excessive alcohol consumption and membership in a fraternity group of an American university, found that self-consciousness (public or private) did not interfere in the consumption of non-members, but acted as a protective factor among male members. Among female members, however, higher levels of private self-consciousness and public self-consciousness raised alcohol intake levels, suggesting that among women in this social group, drinking could function as a mechanism for dealing with negative emotions motivated by disparities between what one is and the idealized version of the self.

Another study (Labrie, Hummer, et al., 2008) concluded that the relationship between alcohol consumption, self-consciousness and gender is affected by perceived social norms or attitude-guiding beliefs (injunctive norms) and the typical behaviors (descriptive norms) of college students. In general, there was a stronger association between perceived norms and consumption in men than in women, a result that was evidenced mainly among students with higher levels of private self-consciousness and lower public self-consciousness.

The results of this research (Labrie, Hummer, et al., 2008) indicated lower alcohol consumption among those with higher private self-consciousness and social anxiety scores and who were influenced by injunctive 
norms. Individuals with this profile would be guided by their own values and behaviors and would be less subject to possible cognitive dissonance. On the other hand, higher consumption was registered among men with higher private self-consciousness and social anxiety and lower public self-consciousness scores, and that perceived the behavior of others in relation to alcohol as permissive.

The sometimes negative and sometimes positive relationship between private self-consciousness and alcohol consumption seems to be also influenced by implicit attitudes such as implicit drinking identity and drink refusal self-efficacy (Foster et al., 2014). A study by Foster, Neighbors, and Young (2014) found that in individuals whose efficacy in refusing alcohol was low, higher levels of identification with drinking behavior were associated with more frequent consumption when their private self-consciousness levels were low. However, among those with great difficulty in "saying no" to alcohol, but who identified themselves less as drinkers, the frequency of consumption and the private self-consciousness levels varied in the same direction. The same did not occur among those who thought they could deny a drink.

Researchers (Foster et al., 2014) concluded that while people who find it difficult to refuse a drink may experience a dilemma between implicit attitude and behavior, individuals who claim having ease to refuse a drink will not necessarily use alcohol to reduce possible discomfort resulting from self-consciousness. With regard to drinking identity, those who do not perceive themselves as consumers are perhaps more susceptible to the influence of intra and interpersonal stimuli, whereas assumed drinkers seem to consume independently of their level of self-consciousness.

Similarly, Timary et al. (2013) argue that alcohol can be used by some to reduce the state of self-consciousness, thus avoiding contact with aversive or adverse situations. A research with alcoholics in treatment for detoxification has shown that in less self-conscious patients (private or public self-consciousness), depression levels did not affect the intensity of craving before or after the intervention program (Timary et al., 2013). However, for higher levels of self-consciousness (private or public), depression levels were positively related to craving, suggesting that in these individuals, alcohol could act as an "antidepressant" (Timary et al., 2013, p.5). For the researchers, this is due to the fact that negative aspects associated with private self-consciousness and public self-consciousness, such as rumination, self-stigma and guilt, which are common in depressive episodes, hamper proper information processing and consequent self-regulation.

Although more introspective individuals are guided by their own thoughts and behaviors, the results of the analyzed publications (Bartholow et al., 2000; Foster et al., 2014; LaBrie, Hummer, et al., 2008; LaBrie, Pedersen, et al., 2008; Park et al., 2006) suggest the influence of environmental factors on the relationship between self-consciousness and alcohol consumption. Individuals can drink more or less depending on their ability to perceive, process, monitor and evaluate information (internal and external) and experiences, at the moment of life in which they find themselves.

The evaluation of this capacity in contexts that demand self-regulation was proposed by Grant, Franklin, and Langford (2002). According to them, private self-consciousness is subdivided into the dimensions of self-reflection and insight. While the former is associated with reflection and with monitoring one's own thoughts, feelings and behaviors, the second involves understanding, evaluating and expressing them. The two dimensions make up the two factors of the SelfReflection and Insight Scale (SRI), developed by these authors and validated for the Brazilian population by DaSilveira, DeCastro, and Gomes (2012).

In addition to the original research by Grant et al. (2002), other studies with SRI have observed that insight appears to be associated with adaptive and healthy reactions (Chung, Su, \& Su, 2012; Harrington \& Loffredo, 2011; Harrington, Loffredo, \& Perz, 2016; Lyke, 2009; Silvia \& Phillips, 2011), while self-reflection is related to reactions that are sometimes beneficial (Cowden \& Meyer-Weitz, 2016; Eng \& Pai, 2015; Pai, 2015), sometimes harmful to health (Sauter, Heyne, Blöte, van Widenfelt, \& Westenberg, 2010; Silvia \& Phillips, 2011). The best results are achieved by individuals who employ cognitive and emotional resources in both dimensions of private self-consciousness. That is, successful behavioral adaptations or changes engage the individual both in the self-monitoring of internal aspects (self-reflection) and in the clear understanding and assessment of the self (insight) (Leal, Souza, \& DeSouza, 2018).

This research was guided by this perspective. In view of the variety of individual and environmental factors that may influence alcohol intake, the objective was to analyze the relationship between self-reflection and insight, dimensions of private self-consciousness, and alcohol consumption among young people and 
adults. Based on the results of studies that verified the association of private self-consciousness (measured by the SCS) with alcohol consumption (Bartholow et al., 2000; Foster et al., 2014; LaBrie, Hummer, et al., 2008; LaBrie, Pedersen, et al., 2008; Park et al., 2006; Timary et al., 2013) and on the importance of selfreflection and insight for behavioral self-regulation (Cowden \& Meyer-Weitz, 2016; Chung et al., 2012; Eng \& Pai, 2015; Grant et al., 2002; Harrington \& Loffredo, 2011; Harrington et al., 2016; Leal et al., 2018; Lyke, 2009; Pai, 2015; Sauter et al., 2010; Silvia \& Phillips, 2011), two hypotheses (H) were established. They were: (H1) there is a negative correlation between insight and alcohol consumption and (H2) there is a negative correlation between self-reflection and alcohol consumption, but with weaker intensity than the one presented in the first hypothesis.

The behavior of the variables in relation to gender and age was not predicted, due to the lack of consensus between previous results on the association of private self-consciousness with gender and age (DaSilveira, DeSouza, \& Gomes, 2015; Haga, Kraft, \& Corby, 2009; Leal et al., 2018; Roberts \& Stark, 2008; Sauter et al., 2010), as well as to the absence of studies that verify the relationship between self-reflection, insight and alcohol consumption. Despite that, these associations were investigated on an exploratory basis and their results were reported.

\section{Method}

\section{Participants}

The convenience sample consisted of male and female Brazilians, aged from 20 to 39 years old, drinkers, recruited in public and private higher education institutions, located in Vitoria, state of Espirito Santo, in the southeastern region of Brazil. Of a total of 528 respondents, five were excluded due to not meeting the inclusion criteria $(n=1)$ or to missing data $(n=$ 4). Among the 523 participants, $61.6 \%$ identified themselves as male $(n=322)$, whereas $38.4 \%$ as female $(n$ $=201)$. The mean age was 24.21 years $(S D=4.17)$, $67.3 \%$ belonging to the $20-24$ years age group $(n=$ $352) ; 19.9 \%$ to the $25-29$ years age group $(n=104)$; $9.2 \%$ to the $30-34$ years age group $(n=48)$; and $3.6 \%$ to the 35-39 years age group $(n=19)$.

With regard to education level, just over half $(58.5 \%$ of the total) were enrolled in private educational institutions. Of the total number of students, $58.9 \%$ attended night classes, $34.4 \%$ daytime and $6.7 \%$ afternoon classes on Social Sciences (47.2\%), Engineering (29.3\%), Health Sciences (15.3\%) and Exact and Earth Sciences (7.6\%). Three respondents $(0.6 \%)$ did not report their area of study. The majority had incomplete undergraduate degrees $(83.2 \%)$, whereas a smaller group was still attending a graduate program $(6.9 \%)$, or had already completed an undergraduate course $(5.9 \%)$ or a graduate program $(4.0 \%)$. Of the total sample, 94.1\% were from the Southeast region of Brazil: $83.7 \%$ from Espirito Santo, 6.1\% from Minas Gerais, 3.3\% from Rio de Janeiro, and 1.0\% from São Paulo. The remaining $5.9 \%$ were divided between states located in other regions of the country: Northeast $(2.5 \%)$, South $(1.7 \%)$, North $(0.8 \%)$ and Midwest $(0.2 \%)$, while $0.8 \%$ did not report their region of origin.

\section{Instruments}

a) Self-reflection and Insight Scale (SRI). The SRI is composed of 20 items, 12 referring to the self-reflection dimension and eight referring to the insight dimension. The respective values of alpha (a) of the Brazilian version of the SRI are .902 and .825 (DaSilveira, DeCastro, \& Gomes, 2012). The self-reflection dimension refers to statements that evaluate the individual's ability to self-monitor or reflect on one's own thoughts, feelings and behaviors, while the insight dimension explores the ability to understand what one is feeling or the reasons for one's behavior. The Likert scale used followed the proposal of the Brazilian version, with the participants' answer options varying from 0 (totally disagree) to 4 (totally agree). The maximum SRI scores are 48 points for the self-reflection dimension and 32 points for the insight dimension. Negative affirmations (items 1, 2, 4, 7, 14, 16, 17, 18 and 19 in the Brazilian version of the scale) had their scores reversed before the sum (Grant et al., 2002).

b) Alcohol Use Disorders Identification Test (AUDIT). It is used for screening problems related to the ingestion of alcoholic beverages. It was developed by WHO (Saunders, Aasland, Babor, Fuente, \& Grant, 1993) and validated in Brazil by Lima et al. (2005) $(a=.81)$. The AUDIT has ten items regarding the number of doses ingested and the frequency of behaviors and events associated with alcohol consumption (e.g., drinking to feel better, feeling guilty, self-harming or harming someone, etc.). In each item, the alternatives vary from 0 (always related to behaviors with low risk 
to health, such as 1 to 2 doses; Never) to 4 (always related to behaviors indicative of risk or potential harm, such as 10 or more doses; four or more times per week). Although individual differences influence the effect of alcohol on the body, WHO suggests that scores equal to or lower than 7 indicate a low risk of developing problems related to alcohol use; between 8 and 15, risky alcohol consumption; between 16 and 19, need for counseling and follow-up; and equal to or above 20, warrant further diagnostic evaluation for possible dependence (Babor, Higgins-Biddle, Saunders, \& Miller, 2001). The maximum score on the test is 40 . As alcohol consumption was established as a criterion for participation in this study, the minimum score considered was 1 .

\section{Data collection procedures}

The instruments were reproduced on paper and the application took place, in person and collectively, during the morning, afternoon and night classes, in rooms of four educational institutions (one public and three private), in five campuses, access to them having been granted by professors, course coordinators or directors of the institutions. After receiving general explanations about the research and the participation criteria, students who signed the Free and Informed Consent form were asked to fill out questionnaires individually. The approach and application process lasted, on average, 30 minutes per room. This research respected the ethical guidelines established by Resolution CNS 466/12 and had its execution approved by the Human Research Ethics Committee of the Federal University of Espirito Santo (CAAE 54381816.4.0000.5542).

\section{Data analysis procedures}

Data were submitted to statistical analysis in the IBM ${ }^{\circledR}$ SPSS ${ }^{\circledR}$ software, version 22. Descriptive statistics were conducted for the characterization of the sample and analysis of data distribution, calculated based on frequency, mean and standard deviation. In addition, Pearson product-moment correlation coefficient $(r)$ (one-tailed), Chi-square test $\left(\chi^{2}\right)$, Analysis of Variance (ANOVA) and Student's t-Test were used to test hypotheses $\mathrm{H} 1$ and $\mathrm{H} 2$. The sample was divided by gender, male and female, and age groups young people, aged from 20 to 29 years old $(n=456)$ and adults, aged from 30 to 39 years old $(n=67)$, according to the classification of the Brazilian Young Statute (Law No. 12,852/2013), which considers young people to be those aged between 15 and 29 years old. Regarding alcohol consumption, in addition to the total AUDIT score, two major groups were considered: low risk corresponded to those who scored from 1 to 7 on the screening test $(n=269)$ and risk corresponded to the other participants $(n=254)$.

The criteria established by Dancey and Reidy (2013) guided the analysis of the strength or magnitude of the relationship between the investigated variables, due to the absence of similar previous studies with correlation coefficients $(r)$ that could serve as parameters. Thus, values of $r$ in the range between 0.1 and 0.3 were considered to be low intensity; between 0.4 and 0.6 , moderate; and above 0.7 , strong. For all inferential analyses, 95\% confidence interval $(p<.05)$ was adopted.

\section{Results}

Regarding private self-consciousness, the means of the total sample were $35.51(S D=7.60)$ for selfreflection $(\mathrm{CI}=34.86,36.17)$ and $18.02(S D=5.94)$ for insight $(\mathrm{CI}=17.51,18.53)$. Significant statistical mean differences between women and men in relation to self-reflection and insight were verified, with women scoring more than men in self-reflection $[t(521)=-3.45$, $p=.001]$, and men scoring more than women in insight $[t(521)=4.32, p<.001]$. In terms of age, the means in the dimensions of private self-consciousness grew with the advancement of age in the sample. Adults (30 to 39 years old) showed higher levels of self-reflection $[t(521)$ $=-2.20, p=.028]$ and insight $[t(521)=-2.42, p=.016]$ than young people (20 to 29 years old). Complementary statistics are presented in Table 1.

Concerning alcohol consumption, slightly more than half $(51.4 \%)$ of the participants fit into what WHO considers as low risk, $40.5 \%$ were classified as risk, and $8.0 \%$ were sorted in a group whose behavior indicated a need for counseling (3.8\%) and possible dependence $(4.2 \%)$. It is worth noting that $57.6 \%$ reported occasionally consuming alcoholic beverages in a month (two to four times), while approximately one in five participants had a weekly frequency (two to three times). In relation to number of doses, $61.9 \%$ stated that they had five or more doses when they drank, and of those, $10.3 \%$ admitted that they could exceed ten doses. One-quarter of the sample (approximately two men for each woman) reported heavy consumption, that is, six or more doses on a single occasion, two to four times a month, and 7.8\% (6.1\% of men), two or three times a week. 
With reference to gender, men reported drinking significantly more than women $[t(521)=2.18, p=$ .029]. In the age group, although young people drink, on average, more than adults, this difference was not statistically significant $[t(521)=1.22, p=.223]$ when the overall AUDIT score was assessed. Table 1 also shows the main descriptive and inferential results regarding the alcohol consumption pattern of the participants according to their gender and age group.

Table 1.

Mean, Standard Deviation and Mean Differences for Self-reflection, Insight and Alcohol Consumption

Descriptive Statistics

\begin{tabular}{lcccccccc}
\hline & Groups & M & SD & SE & \multicolumn{2}{c}{$95 \%$ CI } & Min & Max \\
\hline Self-reflection & & & & & L & U & & \\
& Male & 34.62 & 7.60 & 0.42 & 33.79 & 35.45 & 12 & 48 \\
& Female & 36.95 & 7.40 & 0.52 & 35.92 & 37.98 & 13 & 48 \\
& Young & 35.23 & 7.65 & 0.36 & 34.53 & 35.94 & 12 & 48 \\
& Adult & 37.42 & 7.03 & 0.86 & 35.70 & 39.13 & 16 & 48 \\
Insight & & & & & & & & \\
& Male & 18.89 & 5.69 & 0.32 & 18.27 & 19.52 & 2 & 32 \\
& Female & 16.63 & 6.08 & 0.43 & 15.78 & 17.47 & 3 & 32 \\
& Young & 17.78 & 5.86 & 0.28 & 17.24 & 18.32 & 2 & 32 \\
Alcohol & Adult & 19.66 & 6.22 & 0.76 & 18.14 & 21.17 & 3 & 32 \\
& & & & & & & & 25 \\
& Male & 8.68 & 4.81 & 0.27 & 8.15 & 9.21 & 1 & 23 \\
& Female & 7.75 & 4.67 & 0.33 & 7.10 & 8.40 & 1 & 25 \\
& Young & 8.42 & 4.81 & 0.23 & 7.98 & 8.86 & 1 & 25 \\
& Adult & 7.66 & 4.51 & 0.55 & 6.56 & 8.76 & 1 & 20 \\
& & & & & & & & \\
\end{tabular}

Student's t Test for Independent Samples by Gender and Age Group

\begin{tabular}{lccccccc}
\hline & Groups & $\mathrm{t}$ & $\mathrm{df}$ & $\begin{array}{c}\text { Mean } \\
\text { Difference }\end{array}$ & $\begin{array}{c}\text { SE } \\
\text { Mean }\end{array}$ & \multicolumn{2}{c}{$95 \% \mathrm{CI}$} \\
\hline Self-reflection & & & & & & $\mathrm{L}$ & $\mathrm{U}$ \\
& Gender & $-3.45^{* * *}$ & 521 & -2.33 & 0.68 & -3.66 & -1.00 \\
& Age & $-2.20^{*}$ & 521 & -2.18 & 0.99 & -4.13 & -0.24 \\
& group & & & & & & \\
Insight & & & & & & & \\
& Gender & $4.32^{* * *}$ & 521 & 2.27 & 0.53 & 1.24 & 3.30 \\
& Age & $-2.42^{*}$ & 521 & -1.87 & 0.77 & -3.39 & -0.36 \\
Alcohol & group & & & & & & \\
consumption & & & & & & & \\
& Gender & $2.18^{*}$ & 521 & 0.93 & 0.43 & 0.09 & 1.77 \\
& Age & 1.22 & 521 & 0.76 & 0.63 & -0.47 & 1.99 \\
& group & & & & & & \\
\hline
\end{tabular}

Note. ${ }^{*} \mathrm{p}<.05 ;{ }^{* * *} \mathrm{p} \leq .001$ (two-tailed test). 
The correlation analysis confirmed the two research hypotheses, revealing statistically significant but weak negative correlations between insight and alcohol consumption (H1) $(r=-.26, p<.001)$ and selfreflection and alcohol consumption $(\mathrm{H} 2)(r=-.10, p=$ .010). The results are summarized in Table 2.

It is noted that as predicted in $\mathrm{H} 2$, the correlation between self-reflection and alcohol consumption was less intense than the correlation between insight and consumption. However, lower levels of private self-consciousness, in its self-reflection and insight dimensions, were associated with higher levels of alcohol intake among the young people and adults surveyed.

In the sample's grouping by gender, insight and alcohol consumption were significantly negatively correlated, although weakly, in men $(r=-.28, p<.001)$ and also in women $(r=-.29, p<.001)$. Self-reflection was not related to consumption in the groups divided by gender, a result that differed from the total sample's. In the groups sorted according to age, among young people, negative correlations were found between alcohol consumption and self-reflection $(r=-.10, p=.019)$; and alcohol consumption and insight $(r=-.26, p<.001)$. In the group of adults, only insight was negatively associated with consumption, but the correlation coefficient was slightly lower $(r=-.20, p=.050)$.

The results of tests $\chi^{2} 2 \times 2$, which investigated the association of alcohol consumption levels (low risk and risk) with gender and also with age group, indicated that there is no significant difference between consumption levels in the groups sorted by gender $\left[\chi^{2}(1)=1.88, p=.171\right]$, only in those sorted by age group $\left[\chi^{2}(1)=6.24, p=.013\right]$. In this group, among adults, almost twice as many participants $(65.7 \%$ vs $34.3 \%$ ) have consumption patterns considered as low risk, whereas among young people, the percentage of low risk (49.3\%) and risk (50.7\%) are similar, with a slight prevalence of the latter.
When two-way ANOVA was performed, considering the levels of alcohol consumption (low risk and risk) and gender, with self-reflection as a dependent variable, there was a significant effect of gender $\left[F f_{1}\right.$, $\left.\left.{ }_{519}\right)=11.03, p=.001\right]$ but not of alcohol consumption levels $[F(1,519)=3.03, p=.082]$ or of the interaction between them $\left[F\left({ }_{1,519}\right)=0.104, p=.747\right]$. With insight as a dependent variable, a significant effect of both gen$\operatorname{der}\left[F\left({ }_{1,519}\right)=23.23, p<.001\right]$ and alcohol consumption levels $\left[F\left({ }_{1,519}\right)=37.91, p<.001\right]$ was observed, but not of the interaction between them $\left[F\left({ }_{1,519}\right)=0.45, p=\right.$ .504]. Table 3 summarizes the statistical results.

\section{Discussion}

This research was carried out with the objective of verifying the relationship between self-reflection, insight and alcohol consumption among young people and adults. The hypotheses that levels of self-reflection and insight would vary in the opposite direction to those of alcoholic beverage intake were confirmed in a sample of 523 higher-education students from public and private institutions in a metropolitan region of southeastern Brazil, although correlations with weak intensity, such as those presented, should be considered with caution.

One possible explanation for the significant but low magnitude of the results is that other environmental variables, which were not controlled in this study, interfered in the relationship among self-reflection, insight and alcohol consumption. Studies that also pointed to a beneficial relationship between private selfconsciousness and alcohol consumption (Bartholow et al., 2000; Labrie, Pedersen, et al., 2008) found that after inclusion of other variables such as gender and social norms (Park et al., 2006; Labrie, Hummer, et al., 2008), rumination, depression, guilt and self-stigma (Timary et al., 2013), this benefit could not be maintained.

Table 2.

Pearson's Correlation Coefficient (r) for Self-reflection, Insight and Alcohol Consumption by Gender and Age Group

\begin{tabular}{lccccccc}
\hline \multirow{2}{*}{ Correlations } & \multirow{2}{*}{ Total } & & \multicolumn{2}{c}{ Gender } & & \multicolumn{2}{c}{ Age Group } \\
\cline { 7 - 8 } \cline { 7 - 8 } & & & Male & Female & & Young & Adult \\
\hline Self-reflection and Alcohol Consumption & $-.10^{* *}$ & & -.08 & -.11 & & $-.10^{*}$ & -.09 \\
Insight and Alcohol Consumption & $-.26^{* * *}$ & & $-.28^{* * *}$ & $-.29^{* * *}$ & & $-.26^{* * *}$ & $-.20^{*}$ \\
Self-reflection and Insight & $.12^{* *}$ & & $.10^{* *}$ & $.24 * * *$ & & $.10^{*}$ & $.24^{*}$ \\
\hline
\end{tabular}

Note. $*_{\mathrm{p}} \leq .05 ;{ }^{* *} \mathrm{p} \leq .01 ;{ }^{* * *} \mathrm{p} \leq .001$ (one-tailed test). 
Especially in the case of young people, group with higher proportion of participants who exhibit risky consumption patterns, drinking behavior is commonly associated with social issues, the need for integration and autonomy (Domingues et al., 2009; Hummer, et al., 2008). On the one hand, depending on the amount consumed and the environment, alcohol can favor situations of violence, aggression, vulnerability to risk and diseases, such as alcoholism (WHO, 2016); on the other, it can produce feelings of relaxation, euphoria and social disinhibition (Domingues et al., 2009), inciting consumption. In addition, alcohol also works as an antidepressant (Timary et al., 2013) and may be ingested to reduce feelings of low self-esteem, impotence, and frustration to help cope with failure or lack of perspective, and to assist in overcoming challenges (Park et al., 2006; Timary et al., 2013).

In fact, previous studies, which have used the SCS, associate the benefits of private self-consciousness in the reduction of alcohol consumption both with the individual's ability and motivation to respond to emotions or adverse situations (Park et al., 2006), and the need to integrate into a group or social environment (Labrie,
Hummer, et al., 2008; Park et al., 2006). Therefore, it seems reasonable to suggest that a more introspective profile of self-consciousness, despite helping the individual, is not in itself a sufficiently strong or determinant attribute in the reduction of drinking behavior, which would be subject to situational variables.

The somewhat more intense relationship between lower alcohol consumption and greater insight can be explained by the fact that insight is associated with healthier and more adaptive behaviors such as cognitive flexibility and self-regulation (Chung et al., 2012; Grant et al., 2002; Silvia \& Phillips, 2011); reduction of negative affections, depression and anxiety; psychological well-being (Harrington \& Loffredo, 2011) and satisfaction with life (Harrington \& Loffredo, 2011; Lyke, 2009). Self-reflection, on the other hand, can unbalance the psychological equilibrium. Although reflecting on one's own thoughts, feelings, and actions is central to behavioral self-regulation (Grant et al., 2002), excessive investment in cognitive and emotional resources at this stage of the process tends to undermine the individual's progress in solving situations and to intensify negative reactions to their well-being and their responsiveness

Table 3.

Two-way Analysis of Variance of Self-reflection and Insight by Gender and Alcohol Consumption

\begin{tabular}{|c|c|c|c|c|c|c|c|}
\hline \multirow[t]{2}{*}{ Gender $^{a}$} & \multicolumn{2}{|c|}{$\begin{array}{c}\text { Alcohol } \\
\text { Consumption }^{\mathrm{b}}\end{array}$} & \multicolumn{2}{|c|}{$\begin{array}{c}\text { Self- } \\
\text { reflection }\end{array}$} & \multicolumn{2}{|c|}{ Insight } & \multirow[t]{2}{*}{ Inferential statistics } \\
\hline & & $\mathrm{N}$ & $\mathrm{M}$ & $\mathrm{DP}$ & $\mathrm{M}$ & $\mathrm{DP}$ & \\
\hline \multirow[t]{4}{*}{ Male } & Low risk & 158 & 35.11 & 8.03 & 20.66 & 4.89 & Self-reflection as Dependent Variable (DV) \\
\hline & Risk & 164 & 34.15 & 7.15 & 17.20 & 5.89 & $\mathrm{a} \mathrm{F}^{(1,519)}=11.03^{* * *}, \mathrm{p}=.001, \eta 2 \mathrm{p}=.021$ \\
\hline & Total & 322 & 34.62 & 7.60 & 18.89 & 5.69 & $\mathrm{bF}^{(1,519)}=3.03, \mathrm{p}=.082, \eta 2 \mathrm{p}=.006$ \\
\hline & & & & & & & $\mathrm{c} \mathrm{F}^{(1,519)}=0.104, \mathrm{p}=.747, \eta 2 \mathrm{p}=.000$ \\
\hline \multirow[t]{4}{*}{ Female } & Low risk & 111 & 37.58 & 7.33 & 17.87 & 5.71 & \\
\hline & Risk & 90 & 36.18 & 7.45 & 15.09 & 6.20 & Insight as Dependent Variable (DV) \\
\hline & Total & 201 & 36.95 & 7.40 & 16.63 & 6.08 & $\mathrm{a} \mathrm{F}^{(1,519)}=23.23^{* * *}, \mathrm{p}<.001, \eta 2 \mathrm{p}=.043$ \\
\hline & & & & & & & $\mathrm{b} \mathrm{F}^{(1,519)}=37.91 * * *, \mathrm{p}<.001, \eta 2 \mathrm{p}=.068$ \\
\hline \multirow[t]{3}{*}{ Total } & Low risk & 269 & 36.13 & 7.83 & 19.51 & 5.41 & $\mathrm{c} \mathrm{F}^{(1,519)}=0.45, \mathrm{p}=.504, \eta 2 \mathrm{p}=.001$ \\
\hline & Risk & 254 & 34.87 & 7.31 & 16.45 & 6.08 & \\
\hline & Total & 523 & 35.51 & 7.60 & 18.02 & 5.94 & \\
\hline
\end{tabular}

Note.

a Gender's main effect on DV

b Alcohol consumption's main effect on DV

c Effect of the interaction between gender and alcohol consumption on DV

$* * * \mathrm{p} \leq .001$ 
to the social environment (Leal et al., 2018). Rumination (Sauter et al., 2010; Silvia \& Phillips, 2011; Timary et al., 2013), anxiety (Grant et al., 2002), depression (Silvia \& Phillips, 2011; Timary et al., 2013) and stress (Grant et al., 2002; Silvia \& Phillips, 2011) exemplify these reactions.

Also in the context of alcohol consumption among the young people and adults surveyed, the beneficial role of insight seems to have manifested itself more strongly in regulating behavior. The role of selfreflection, however, indicated that it was more sensitive to the influence of other factors. In addition, the significant but weak positive correlations observed between self-reflection and insight suggest that the strength of the relationship between the dimensions of private self-consciousness, which is necessary for proper selfregulation (Grant et al., 2002), may have affected the strength of the association between the variables of self-consciousness and alcohol consumption.

Although there is no consensus in the literature on the effects of gender and age on self-reflection and insight (Leal et al., 2018), the results found both for self-reflection (women with higher scores) and for insight (men with higher scores) corroborate the findings of DaSilveira et al. (2015) and Roberts and Stark (2008), respectively. In relation to the effects of age group, in agreement with other authors (Haga et al., 2009; Roberts \& Stark, 2008), insight had a statistically higher mean value among adults in the sample. This fact reinforces the role of the insight dimension in private self-consciousness and may explain the lower rate of engagement of this group in risky alcohol intake.

As suggested by Bartholow, Sher, and Strathman (2000), the findings of this study could also be interpreted as the result of the influence of the individual's cognitive development on their involvement with alcohol. That is, psychosocial experiences and interactions, which allow individuals to broaden their self-reflexive and self-assessed capacity to self-regulate (Grant et al., 2002), generally more extensive and consolidated in adulthood, would benefit those who are older. However, due to the absence of interaction between the variables of private self-consciousness and levels of alcohol consumption (low risk and risk), caution is recommended in this analysis.

In summary, in this study, higher levels of private self-consciousness indicated lower levels of alcohol consumption, suggesting that self-reflection and insight may act as regulators of this behavior. This benefits both the users themselves and society, if we consider that the abusive consumption of alcoholic beverages or the ingestion associated with activities that demand full cognitive functioning are, demonstrably, potential triggers of damages and losses (Domingues et al., 2009; Melcop et al., 2011; WHO, 2014).

\section{Final considerations}

This research, which evaluated the application of the regulatory cycle model of Grant et al. (2002) to alcohol users, found a negative correlation among self-reflection, insight and alcohol consumption. From these findings, it is proposed that in the whole cycle of self-regulation, which involves definition of objectives, planning, action, monitoring, evaluation, and regulation (Grant et al., 2002), context and behaviors are influenced by a continuous interaction of individual and environmental factors. Especially in the self-reflexive stage, individuals' attitudes and reactions to the context may favor the continuity and the balance of the self-regulation process (progress to the self-assessment stage, associated with insight) or discontinue and unbalance it (in the case of alcohol consumption, make it abusive).

In this scenario, intervention programs can be strategic in mapping social contexts and in identifying stressors and possible sources of cognitive dissonance for promoting healthcare. Similarly, adopting such strategies would be important to address, mobilize, cope with or reduce harm when harmful consumption and dependency is already a reality. In agreement with other researchers (Cowden \& Meyer-Weitz, 2016; Eng \& Pai, 2015; Grant et al., 2002; Pai, 2015), it is believed that the improvement of self-reflexive skills and insight, with the more adequate use of cognitive and emotional resources, broadens the possibilities of action of individuals as it helps them to handle the demands, adversities and conflicts imposed by life.

It should be noted that alcohol consumption itself must no be classified as an unwelcomed behavior. This would go against the subjective, social and cultural meanings that, historically, are linked to the use of alcoholic beverages. What needs to be addressed are harmful intake and its association with risky behaviors, promoting the population's access to information, adequate health and education services, psychosocial support and less perverse living conditions.

Although statistically significant, the results of this study require further investigation because of limitations of sample size, collection environment, 
and possibly the private self-consciousness assessment instrument. A sample that is more homogeneous in its distribution in the different levels of alcohol consumption, or methodological delineations that allow us to verify, in simulated situations of consumption and/or potential risk, how self-reflexive processes and insight occur in alcohol users (especially among those with higher consumption frequency) are recommended. Examining these processes during the performance of a task, for example, could promote a deeper understanding of the relationship between different levels or styles of self-consciousness and behavior, and support the development of more effective public policies and intervention strategies that respect individual differences and potentialities.

\section{References}

Babor, T. F., Higgins-Biddle, J. C., Saunders, J. B., \& Monteiro, M. G. (2001). AUDIT - The alcohol use disorders identification test: guidelines for use in primary health care. Retrieved from http://apps.who.int/ iris/bitstream/10665/67205/1/WHO_MSD_ MSB_01.6a.pdf

Bartholow, B. D., Sher, K. J., \& Strathman, A. (2000). Moderation of the Expectancy-Alcohol Use Relation by Private Self-Consciousness: Data From a Longitudinal Study. Personality and Social Psychology Bulletin, 26(11), 1409-1420. doi: 10.1177/0146167200263008

Brazilian Institute of Geography and Statistics [IBGE]. (2013). Pesquisa Nacional de Saúde 2013. Percepção do estado de saúde, estilos de vida e doenças crônicas. Retrieved from ftp://ftp.ibge.gov.br/PNS/2013/ pns2013.pdf

Chung, S.-H., Su, Y.-F., \& Su, S.-W. (2012). The impact of cognitive flexibility on resistance to organizational change. Social Behavior and Personality, 40(5), 735-746. doi: 10.2224/sbp.2012.40.5.735

Conselho Nacional de Saúde [CSN]. Resolução 466 (2012).

Cowden, R. G., \& Meyer-Weitz, A. (2016). Self-reflection and self-insight predict resilience and stress in competitive tennis. Social Behavior and Personality, 44(7), 1133-1150. doi: 10.2224/sbp.2016.44.7.1133

Dancey, C. P., \& Reidy, J. (2013). Estatística sem matemática para psicologia. Porto Alegre: Penso.
DaSilveira, A. da C., DeCastro, T. G., \& Gomes, W. B. (2012). Escala de Autorreflexão e Insight: Nova Medida de Autoconsciência Adaptada e Validada para Adultos Brasileiros. Psico, 43(2), 155-162. Retrieved from http://revistaseletronicas.pucrs.br/ojs/index.php/revistapsico/article/ viewFile/11693/8039

DaSilveira, A. da C., DeSouza, M. L., \& Gomes, W. B. (2015). Self-consciousness concept and assessment in self-report measures. Frontiers in Psychology, 6(930), 1-11. doi: 10.3389/ fpsyg.2015.00930

Domingues, S. C. A., Mendonça, J. B., Laranjeira, R., \& Nakamura-Palacios, E. M. (2009). Drinking and driving: a decrease in executive frontal functions in young drivers with high blood alcohol concentration. Alcohol, 43(8), 657-664. doi: 10.1016/j. alcohol.2009.10.001

Eng, C.-J., \& Pai, H.-C. (2015). Determinants of nursing competence of nursing students in Taiwan: The role of self-reflection and insight. Nurse Education Today, 35(3), 450-455. doi: 10.1016/j. nedt.2014.11.021

Fenigstein, A., Scheier, M. F., \& Buss, A. H. (1975). Public and Private Self-Consciousness: Assesment and Theory. Journal of Consulting and Clinical Psychology, 43(4), 522-527. doi: 10.1037/h0076760

Foster, D. W., Neighbors, C., \& Young, C. M. (2014). Drink refusal self-efficacy and implicit drinking identity: An evaluation of moderators of the relationship between self-awareness and drinking behavior. Addictive Behaviors, 39, 196-204. doi: 10.1016/j.addbeh.2013.09.024

Grant, A. M., Franklin, J., \& Langford, P. (2002). The self-reflection and insight scale: A new measure of private self-consciousness. Social Behavior and Personality: an International Journal, 30(8), 821-835. doi: 10.2224/sbp.2002.30.8.821

Haga, S. M., Kraft, P., \& Corby, E-K. (2009). Emotion Regulation: Antecedents and Well-Being Outcomes of Cognitive Reappraisal and Expressive Suppression in Cross-Cultural Samples. Journal of Happiness Studies, 10(3), 271-291. doi: 10.1007/ s10902-007-9080-3

Harrington, R., \& Loffredo, D. A. (2011). Insight, Rumination, and Self-Reflection as Predictors of Well-Being. The Journal of Psychology, 145(1), 39-57. doi: 10.1080/00223980.2010.528072 
Harrington, R., Loffredo, D. A, \& Perz, C. A. (2016). Dispositional mindfulness facets and self-insight as predictors of subjective well-being: an exploratory analysis. North American Journal of Psychology, 18(3), 469-482.

LaBrie, J., Hummer, J. F., \& Neighbors, C. (2008). Selfconsciousness moderates the relationship between perceived norms and drinking in college students. Addictive Behaviors, 33(12), 1529-1539. doi: 10.1016/j.addbeh.2008.07.008

LaBrie, J., Pedersen, E. R., Neighbors, C., \& Hummer, J. F. (2008). The role of self-consciousness in the experience of alcohol-related consequences among college students. Addictive Behaviors, 33(6), 812-820. doi:10.1016/j.addbeh.2008.01.002

Leal, C. K. N., Souza, M. D. P. de, \& DeSouza, M. L. (2018). Autorreflexão e insight como dimensões da autoconsciência privada: Uma revisão da literatura. Psico, 49, 231-241.

Lei n. 12.852, de 05 de agosto de 2013. (2013). Institui o Estatuto da Juventude. Diário Oficial da República Federativa do Brasil. Poder Executivo, Brasília, DF.

Lima, C. T., Freire, A. C. C., Silva, A. P. B., Teixeira, R. M., Farrell, M., \& Prince, M. (2005). Concurrent and construct validity of the AUDIT in an urban Brazilian sample. Alcohol and Alcoholism, 40(6), 584589. doi: $10.1093 /$ alcalc/agh202

Lyke, J. A. (2009). Insight but not self-reflection, is related to subjective well-being. Personality and Individual Differences, 46(1), 66-70. doi:10.1016/j. paid.2008.09.010

Madruga, C. S. (2016). Resultados comparativos do Brasil e outros 20 países sobre os padrões de consumo de álcool e cocaina. Paper presented at XXXIV Congresso Brasileiro de Psiquiatria, São Paulo, Brasil. doi: 10.13140/RG.2.2.30018.17600

Melcop, A. G. T., Chagas, D. M. M., \& Agripino, D. A., Filho. (2011). O consumo de álcool e os acidentes de trânsito: pesquisa sobre a associação entre o consumo de álcool e os acidentados de trânsito nas cinco regiōes brasileiras. Retrieved from http://docplayer.com. br/6132103-Pesquisa-sobre-a-associacao-entre-oconsumo-de-alcool-e-os-acidentados-de-transitonas-cinco-regioes-brasileiras.html

Pai, H.-C. (2015). The Effect of a Self-reflection and Insight program on the nursing competence of nursing students: a longitudinal study. Journal of Professional Nursing, 31(5), 424-431. doi: 10.1016/j. profnurs.2015.03.003

Park, A., Sher, K. J., \& Krull, J. L. (2006). Individual Differences in the "Greek Effect" on Risky Drinking: The Role of Self-Consciousness. Psychology of Addictive Behaviors, 20(1), 85-90. doi: 10.1037/0893-164X.20.1.85

Reisdorfer, E., Büchele, F., Pires, R. O. M., \& Boing, A. F. (2012). Prevalence and associated factors with alcohol use disorders among adults: a population-based study in southern Brazil. Revista Brasileira de Epidemiologia, 15(3), 582-594. doi: 10.1590/S1415-790X2012000300012

Roberts, C., \& Stark, P. (2008). Readiness for self-directed change professional behaviours: factorial validation of the Self-reflection and Insight Scale. Medical Education, 42(11), 1054-1063. doi: 10.1111/j.1365-2923.2008.03156.x

Saunders, J. B., Aasland, O. G., Babor, T. F., Fuente, J. R. de la, \& Grant, M. (1993). Development of the Alcohol Use Disorders Identification Test (AUDIT): WHO collaborative project on early detection of persons with harmful alcohol consumption-II. Addiction, 88(6), 791-804. doi: 10.1111/j.13600443.1993.tb02093.x

Sauter, F. M., Heyne, D., Blöte, A. W., van Widenfelt, B. M., \& Westenberg, P. M. (2010). Assessing Therapy-Relevant Cognitive Capacities in Young People: Development and Psychometric Evaluation of the Self-Reflection and Insight Scale for Youth. Behavioural and Cognitive Psychotherapy, 38(3), 303-317. doi:10.1017/S1352465810000020

Silvia, P. J., \& Phillips, A. G. (2011). Evaluating self-reflection and insight as self-conscious traits. Personality and Individual Differences, 50(2), 234-237. doi: 10.1016/j.paid.2010.09.035

Squeglia, L. M., \& Gray, K. M. (2016). Alcohol and Drug Use and the Developing Brain. Current Psychiatry Reports, 18(5), 46. doi:10.1007/s11920-016-0689-y.

Timary, P. de, Uva, M. C. S. de, Denöel, C., Hebborn, L., Derely, M., Desseilles, M., \& Luminet, O. (2013). The Associations between Self-Consciousness, Depressive State and Craving to Drink among Alcohol Dependent Patients Undergoing Protracted Withdrawal. PLoS ONE, 8(8), 1-9. doi:10.1371/ journal.pone.0071560 
West, R. (2013). EMCDDA Insights Series ñ 14. Models of addiction. European Monitoring Centre for Drugs and Drug Addiction. Luxembourg: Publications Office of the European Union. doi: 10.2810/99994

World Health Organization [WHO]. (2014). Global status report on alcohol and health 2014. Retrieved from http://apps.who.int/iris/bitstre am/10665/112736/1/9789240692763_eng.pdf
World Health Organization [WHO]. (2016). Drug use and road safety: a police brief. Recuperado de http:/ / www.who.int/violence_injury_prevention/publications/road_traffic/Drug_use_and_road_safety. pdf

Recebido em: 07/05/2018

Reformulado em: 19/09/2018

Aprovado em: 07/11/2018

About the authors:

Cristyan Karla Nogueira Leal. Master in Psychology, Universidade Federal do Espírito Santo.

ORCID: https://orcid.org/0000-0002-0325-3308

E-mail:leal.ckn@gmail.com

Gabriel Gonzaga Barbosa de Faria. Psychology undergraduate student, Universidade Federal do Espírito Santo.

ORCID: https://orcid.org/0000-0001-7255-2136

Mariane Lima DeSouza. Senior Lecturer at the Universidade Federal do Espírito Santo.

Contact:

Rua Genserico Encarnação, 185/304C, Mata da Praia

Vitória-ES, Brasil

CEP: 29065-420 